○小野寺洋・豊島英仁・荣原重喜 同放射線医学研究部 犬上 篤

諸言および目的：画像診断におけるDSA は，その方 式が，静脈性，動脈性であれその有用性については論議 の余地はない, 一方, その画質については, 徒来の conventional angiography 亿劣るため, メーカおよびユー ザの両サイドから種々検討, 研究が行われている. 私共 は，83年 3 月より DSA 装置 Angiotron 導入した。特 に脳血管造影に多用している。しかし脳血管造影像は， 血管走行が複雑であり, 互に重なり合い, 読影上困難を 来たす、私共は，乙れらを解決する一方法として，ステ レオ DSA の実用化を検討したので報告する，

方法：まず第 1 に，(1)頭部を左右にシーソ運動させる 装置（手製）により，二枚一組のステレオ DSA 像を得 る方法 (一管球方式), (2)現在使用中のX線管に, 新たにX 線管を平行にセットし，X線パルスモード(試作回路)で 曝射し，ステレオ DSA 像を得る方法（二管球方式）の 検討を行った，本システムは，天井走行装置，管球支持 器アルコスコープの重量制限から, 附加X線管は台座上 に固定を余俄なくされた。

結果：私共が, 彷来施行していた, 造影剤二回注入と X線管角度移動方式による, ステレオ DSA 画像に比 較し，(1)シーソ運動方式は鮮鋭度では若干劣るが，臨床 上問題はなく十分読影に有効であった。(2)シーソ運動に より, DSA 装置を改造するととなく経済的であった。(3) 但し本法は，頭頸部に運動制限を有する患者および，頭 部以外の部位には不可能である。(4)二管球方式は, 蹦床 使用に致っていないが, 脳梗塞実験犬でのステレオDSA 像では，良好に疾患部が撮影されている。(5)画方式其に， 画像数は $2 \mathrm{fram} / 1.5 \mathrm{sec}$ となり, 動脈相, 中間相, 静脈 相のステレオ像が得られた。

若察：両方式共に，良好なステレオDS 像が得られた。 私共は，頭部以外や静脈性 DSA でのステレオ化を可能 とすべく，造影剤一回注入による，一管球方式（集点移 動）を検討中である。

\section{0. ステレオ DSA}

山形大学医学部附属病院放射線部

○加賀勇治・木内繁夫

丹 義雄・鈴木隆二

東芝那須工場放射線技術部

西尾功作・安原 引

目的：最近, DSAの画質向上に伴って，ステレオ
DSA の要求が高まっている，ステレオ DSA には，2 回 造影法や 1 回造影で被写体を動かす方法などがある。し かし, 造影剂注入量や撮影体位の制約および撮影プログ ラムの制限など，多くの問題点があって実用化の段階に 到っていない.

私どもは，14インチ I・I，とツインフォーカスX線管 使用による, 交互 $X$ 線曝射·造影剂 1 回注入法でステレオ DSA の実用化を武み，撮影技術上の問題点と撮影プロ グラムについて検討した。

検詥項目

1. 有効視野亡絞り

立体視の有効視野は，焦点間隔，I・I，サイズ，拡大率 によって異なる。私どもは，焦点間隔 $63 \mathrm{~mm}$ で交互に X線曝射し，14，10，7インチサイズにおける至適捩大率 について检討した。さらに，有効視野に応じた正確な絞 り込み方法を検討した。

2. 補償フィルタ

ステレオ DSA 〔怙ける補償フィルタは，左右 $\mathrm{X}$ 線錐 に対灾した補償形態が必要である，撮影部位・方向に応 じた形状に，アタリル板，鉛，增感紙（Gd）を用いて， I.I. 側に簡单に装着できるように作製し，その有用性に ついて検討した。

3. 错察方法

観察は，L側扝よびR側の 2 台の TV モニタ像とフィ ルム像について行い，それぞれの立体感を調べた。

4. 撮影プログラム

タイミングの良いステレオ DSA 画像を得るため，手 動执よび自動トりガーモード術式を適用し，造影部位ご との撮影プログラムについて検討した。

5. 臨床評価

IV DSA およびIA DSA そおけるステレオDSA の有 用性について検討した。

\section{1．血管造影時に併用する DSA の有用 性について}

\section{大垣市民病院放射線科 \\ ○安田鋭介・市川秀男・遠藤斗紀雄 川上文浩・金森勇雄}

Digital Subtraction Angiography（以下, DSA）は， 経静脈性あるいは経動脈性により血管造影を行い, subttraction 像が得られる新しい映像手段として，その登場 以来，大きな期待がよせられてきた。当院にも昭和 57 年 12月から東芝 Digiformer II が既存の血管造影装置に add on されて以来，現在までに約650件の DSA を経験 